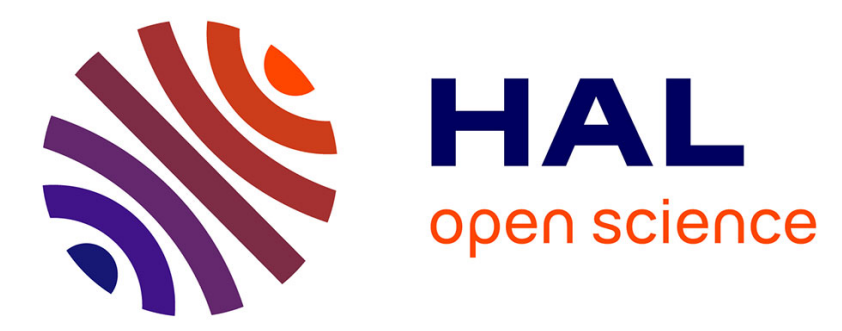

\title{
EXPERIENCE WITH COMPUTER SIMULATION OF A DAIRY POPULATION IN TEACHING ANIMAL BREEDING
}

\author{
H. Schulte-Coerne
}

\section{- To cite this version:}

H. Schulte-Coerne. EXPERIENCE WITH COMPUTER SIMULATION OF A DAIRY POPULATION IN TEACHING ANIMAL BREEDING. Annales de génétique et de sélection animale, 1980, 12 (4), pp.428-428. hal-00893328

\section{HAL Id: hal-00893328 https://hal.science/hal-00893328}

Submitted on 1 Jan 1980

HAL is a multi-disciplinary open access archive for the deposit and dissemination of scientific research documents, whether they are published or not. The documents may come from teaching and research institutions in France or abroad, or from public or private research centers.
L'archive ouverte pluridisciplinaire HAL, est destinée au dépôt et à la diffusion de documents scientifiques de niveau recherche, publiés ou non, émanant des établissements d'enseignement et de recherche français ou étrangers, des laboratoires publics ou privés. 


\title{
VI. - Les ordinateurs pour aider à enseigner l'amélioration génétique en élevage
}

\author{
COMPUTER AIDS FOR TEACHING ANIMAL BREEDING
}

P. M. HOCKING $\left(^{*}\right)$, J. L. FOULLEY $(* *)$, P. H. PETERSEN $(* * *)$, H. SCHULTE-COERNE $(* * * *)$ and A. ZARNECKI $(* * *)$

(*) Department of Agriculture and Horticulture, University of Reading, Reading, England, RG6 $2 A T$

(**) I.N.R.A., 78350 Jouy-en-Josas, France

(***) Institute of Animal Science, The Royal l'eterinary and Agricultural University, 23 Rolighedsvej, r958 Copenhagen, Donmark

(****) Instilut $f$. Tievzucht und Tiev/üterung, University of Bonn, Endenicher Allee $x_{5}, 5300$ Bonn (FRG)

(*****) Department Gcnetics and Animal Brceding, Academy of A griculturc, al Mickiewicza 24/28, 3o-059 Krakow, Poland

The results of a survey of computcr pregrams used in teacling animal breeding is reported. The value of computer teaching aids is discussed and a number of recommendations are made.

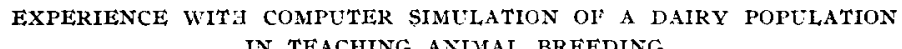
IN TEACHING ANIMAL BREEDING

\section{H. SCHULTE-COERNE}

Institut $f$. Tierzucht und Tier/ütterung der Universität Bonn, Endenicher Allee I5, 5300 Bonn (FRG)

A report is given on a computer generated practical simulating a dairy population. Basic models and practical work are described. Also objectives and principles of teaching are presented and experiences from three year's practicals are discussed. 